\title{
Pitfalls in EEG analysis in patients with non-convulsive status epilepticus
}

Key words: NCSE; interrater agreement; misinterpretation; reliability; seizure

Authors:

Ying Wang ${ }^{1,2,3}$, Ivan C Zibrandtsen ${ }^{4}$, Richard HC Lazeron ${ }^{1,3}$, Johannes P van Dijk ${ }^{1,3}$, Xi

Long ${ }^{1,5}$, Ronald M Aarts ${ }^{1}$, Lei Wang ${ }^{1}$, Johan BAM Arends ${ }^{1,3}$

${ }^{1}$ Department of Electrical Engineering, Eindhoven University of Technology, Eindhoven, the Netherlands

${ }^{2}$ Donders Institute for Brain, Cognition and Behaviour, Radboud University, Nijmegen, the Netherlands

${ }^{3}$ Academic Center for Epileptology Kempenhaeghe, Heeze, the Netherlands

${ }^{4}$ Department of Neurology, Zealand University Hospital, Roskilde, Denmark

${ }^{5}$ Philips Research, Eindhoven, the Netherlands 
medRxiv preprint doi: https://doi.org/10.1101/2020.10.02.20205583; this version posted October 9, 2020. The copyright holder for this preprint (which was not certified by peer review) is the author/funder, who has granted medRxiv a license to display the preprint in All rights reserved. No reuse allowed without permission.

Correspondence: Ying Wang;

Flux 7.062,

Eindhoven University of Technology,

PO Box 513,

5600 MB Eindhoven,

the Netherlands

<y.wang.1@tue.nl; imwywk@gmail.com> 
medRxiv preprint doi: https://doi.org/10.1101/2020.10.02.20205583; this version posted October $9,2020$. The copyright holder for this preprint (which was not certified by peer review) is the author/funder, who has granted medRxiv a license to display the preprint in perpetuity.

All rights reserved. No reuse allowed without permission.

Abstract

Objective.

Electroencephalography (EEG) interpretations through visual (by human raters) and automated (by computer technology) analysis are still not reliable for the diagnosis of nonconvulsive status epilepticus (NCSE). This study aimed to identify typical pitfalls in the EEG analysis and make suggestions as to how those pitfalls might be avoided.

Methods.

We analyzed the EEG recordings of individuals who had clinically confirmed or suspected NCSE. Epileptiform EEG activity during seizures (ictal discharges) were visually analyzed by two independent raters. We investigated whether unreliable EEG visual interpretations quantified by low inter-rater agreement can be predicted by the characteristics of ictal discharges and individuals' clinical data. In addition, the EEG recordings were automatically analyzed by in-house algorithms. To further explore the causes of unreliable EEG interpretations, two epileptologists analyzed EEG patterns most likely misinterpreted as ictal discharges based on the differences between the EEG interpretations through the visual and automated analysis. 
medRxiv preprint doi: https://doi.org/10.1101/2020.10.02.20205583; this version posted October 9 , 2020. The copyright holder for this

preprint (which was not certified by peer review) is the author/funder, who has granted medRxiv a license to display the preprint in perpetuity.

All rights reserved. No reuse allowed without permission.

Results.

Short ictal discharges with a gradual onset (developing over 3 seconds in length) were

liable to be misinterpreted. An extra 2 minutes of ictal discharges contributed to an increase in the kappa statistics of $>0.1$. Other problems were the misinterpretation of abnormal background activity (slow wave activities, other abnormal brain activity, and the ictal-like movement artifacts), continuous interictal discharges, and continuous short ictal discharges.

\section{Conclusion.}

A longer duration criterion for NCSE-EEGs than 10 seconds that commonly used in NCSE working criteria is needed. Using knowledge of historical EEGs, individualized algorithms, and context-dependent alarm thresholds may also avoid the pitfalls. 
medRxiv preprint doi: https://doi.org/10.1101/2020.10.02.20205583; this version posted October 9, 2020. The copyright holder for this preprint (which was not certified by peer review) is the author/funder, who has granted medRxiv a license to display the preprint in All rights reserved. No reuse allowed without permission.

\section{Introduction}

Non-convulsive status epilepticus (NCSE) is characterized by its inconspicuous motor signs with prolonged electrographic seizure activities ${ }^{1}$. Given the subtle and variable clinical presentations, electroencephalography (EEG) that confirms ictal discharges (epileptiform EEG activity during a seizure) is an essential diagnostic tool of NCSE. The reliability of the diagnostic tool can be assessed by the interrater agreement of visual EEG interpretation ${ }^{2}$. A low agreement could indicate the presence of certain EEG misinterpretations and therefore less reliable diagnosis of NCSE ${ }^{3}$.

Currently, NCSE-EEG interpretations through visual analysis by human raters and automated analysis by computer technology are still not very reliable ${ }^{4-10}$. The Salzburg Consensus Criteria (SCC) ${ }^{11,12}$ achieved a reasonably high accuracy and inter-rater agreement among human raters for the diagnosis of $\mathrm{NCSE}{ }^{13,14}$. However, the accuracy and agreement are relatively low when human raters cannot assess the effect of intravenous antiepileptic drugs on the EEG of individuals during NCSE and when raters interpret short EEG recordings ${ }^{5,15,16}$. The visual EEG interpretation relies heavily on subjective judgments based on human raters' experience and knowledge about the characteristics of ictal discharges such as location, morphology, frequency, and persistence. EEGreaders who are inexperienced for NCSE-EEG patterns are more liable to misinterpret EEG, which results in an unreliable NCSE diagnosis. A previous study ${ }^{10}$ summarized several pitfalls in the EEG interpretations of intensive care unit (ICU) patients with NCSE, including misinterpreting artifacts as ictal discharges, assuming that the stereotypical patterns of ictal discharges are observed on the same subject, and assuming that a dichotomy exists between ictal and interictal discharges (epileptiform EEG activity between seizures) in patients with encephalopathy. On the 
medRxiv preprint doi: https://doi.org/10.1101/2020.10.02.20205583; this version posted October 9, 2020. The copyright holder for this preprint (which was not certified by peer review) is the author/funder, who has granted medRxiv a license to display the preprint in All rights reserved. No reuse allowed without permission.

other hand, automated EEG analysis can assist clinicians and care-givers in the detection of ictal discharges because of its greater time efficiency and more objective judgments than visual analysis ${ }^{6-9}$. However, pitfalls of EEG misinterpretations (misclassifications) also exist in automated analysis ${ }^{8,9}$ : the misclassification of pre-ictal discharges (epileptiform EEG activity before a seizure), post-ictal discharges (epileptiform EEG activity after a seizure), high-frequency artifacts, or similar background EEG activity. These misinterpretations of EEG by both human raters and computer technology could lead to wrong diagnoses of NCSE and cause serious consequences ${ }^{17,18}$.

EEG-readers need to be alert to potential pitfalls in EEG analysis for reliable NCSE diagnosis. Nevertheless, studies on the pitfalls in the visual and automated EEG analysis for NCSE are relatively scarce ${ }^{4,10}$. This research therefore addresses the pitfalls of unreliable EEG interpretations in the visual and automated EEG analysis for NCSE patients with chronic epilepsy and brain development disorders. We explored whether the reliability of EEG interpretation can be predicted by the characteristics of ictal discharges and the clinical data of patients. Moreover, we further identified potential pitfalls which could cause EEG misinterpretations and therefore low reliability in the NCSE diagnosis. Strategies to avoid the pitfalls were also proposed in this study.

\section{Materials and methods}

\subsection{Study design}

This is a retrospective explorative study approved by the Medical Research Ethics Committee of Kempenhaeghe in the Netherlands. We retrieved and analyzed the EEG and the clinical records of 30 subjects with preceding seizures between 2008 and 2016 in this study. Twenty of the 30 subjects' 
medRxiv preprint doi: https://doi.org/10.1101/2020.10.02.20205583; this version posted October 9, 2020. The copyright holder for this preprint (which was not certified by peer review) is the author/funder, who has granted medRxiv a license to display the preprint in All rights reserved. No reuse allowed without permission.

data were recorded when they had clinically confirmed NCSE, which was diagnosed based on the clinical information, such as clinical signs, response to treatment, and EEG recordings. The other ten subjects' data were recorded during clinically suspected NCSE, that is, the subjects were first suspected to have NCSE based on clinical signs, but the suspicion was disconfirmed based on the response to treatment and EEG recordings. We included subjects $<65$ years and excluded EEG recordings with excessive artifacts and those of subjects from whom we did not receive permission (from themselves and/or their legal guardians) to use their recordings for scientific research.

The study had three phases. (1) Subjects' data were screened according to the inclusion and exclusion criteria, and the clinical background was evaluated by an experienced epileptologist. (2) Ictal discharges in the EEG recordings were annotated by two independent raters. (3) Pitfalls in the visual and automated EEG analysis were investigated.

\subsection{Data sources}

The EEG recordings were acquired by three different systems (BrainRT equipment from Onafhankelijke Software Groep, EEG Stellate from Natus Europe GmbH, and Micromed from SIGMA Medizin-Technik GmbH) at Kempenhaeghe. The sampling rate of the EEG recordings was $100 \mathrm{~Hz}, 200 \mathrm{~Hz}$, or $256 \mathrm{~Hz}$. EEG electrodes were positioned in the 10-20 system. For the algorithm development of the automated EEG analysis, 21 electrodes were used (19 electrodes in the 10-20 system, plus electrodes F9 and F10). All recordings were continuous except in nine subjects, where 5 minutes per hour were stored when no clinical abnormalities were recorded. From each subject's clinical data and the corresponding clinical report of EEG recordings, we 
medRxiv preprint doi: https://doi.org/10.1101/2020.10.02.20205583; this version posted October 9, 2020. The copyright holder for this preprint (which was not certified by peer review) is the author/funder, who has granted medRxiv a license to display the preprint in All rights reserved. No reuse allowed without permission.

collected information about age, sex, intellectual disability level, sleep status, preexisting epileptic encephalopathy (defined as severe brain dysfunction at early age), clinical signs during NCSE, and seizure history.

\subsection{EEG visual analysis and inter-rater agreement}

The raters were asked to focus on the EEG visual analysis without checking corresponding videos, as NCSE is known by its difficult discrimination from normal behavior, and the fact that different patients show variable clinical presentations. Annotations of ictal discharges were made with the assist of the open-source software "EDFbrowser" ${ }^{19}$. Four types of EEG montages were available during the visual analysis, including longitudinal bipolar montage, transverse bipolar montage, average montage, and original archived data montage.

The raters annotated ictal discharges and labeled their characteristics: duration, certainty, onset location, onset visibility, and morphology patterns according to the pre-defined criteria shown in table 1. As NCSE takes a relatively long time to develop and disappear, we set a minimum of 20 seconds as the duration criterion for the EEG pattern. The presence of ictal discharges was primarily assessed according to the combination of both SCC and the American Clinical Neurophysiology Society's Standardized Critical Care EEG Terminology (ACNS) criteria ${ }^{11,12,20}$. The raters categorized the certainty of their annotations as either definite or possible ictal discharges, and the rest of the recordings was categorized as episodes without ictal discharges. In addition, the ictal discharges were labeled either generalized or focal according to their onset location, and their onset visibility were labeled either sudden or gradual according to the ACNS 
medRxiv preprint doi: https://doi.org/10.1101/2020.10.02.20205583; this version posted October 9, 2020. The copyright holder for this preprint (which was not certified by peer review) is the author/funder, who has granted medRxiv a license to display the preprint in perpetuity.

All rights reserved. No reuse allowed without permission.

criteria. Five categories were used to describe the dominant morphology patterns: three of five categories_-"Spike Wave", "Wave", and "Fast Spike" pattern—were summarized from several terms in ACNS criteria, and the other two empirical categories were added- "Seizure-related EMG Artifacts" 21, and "Unknown Type".

Table 1. Annotation criteria of ictal discharges.

\begin{tabular}{|c|c|c|c|c|}
\hline & & Definite ictal discharges & Possible ictal discharges & $\begin{array}{l}\text { Not ictal } \\
\text { discharges }\end{array}$ \\
\hline \multicolumn{2}{|l|}{ Duration } & \multicolumn{2}{|c|}{$\geq 20$ seconds } & $\begin{array}{c}<20 \\
\text { seconds }\end{array}$ \\
\hline Certainty & & $\begin{array}{ll}\text { - } & \text { SW discharges }>2.5 \\
& \text { Hz } \\
\text { - } & \text { Other-pattern evolving } \\
& \text { discharges }>4 \mathrm{~Hz}\end{array}$ & $\begin{array}{ll}- & \text { SW discharges } \leq 2.5 \\
& \text { Hz } \\
\text { - } & \text { Other-pattern evolving } \\
& \text { discharges } \leq 4 \mathrm{~Hz} \\
- & \text { RDA }>0.5 \mathrm{~Hz}\end{array}$ & $\begin{array}{l}\text { Rest EEG } \\
\text { activity }\end{array}$ \\
\hline \multirow{2}{*}{$\begin{array}{l}\text { Onset } \\
\text { location }\end{array}$} & Generalized & \multicolumn{2}{|c|}{ Occupying $>$ half of the longitudinal bipolar channels } & \\
\hline & Focal & \multicolumn{2}{|c|}{ Occupying $\leq$ half of the longitudinal bipolar channels } & \\
\hline \multirow{2}{*}{$\begin{array}{l}\text { Onset } \\
\text { visibility }\end{array}$} & Sudden & \multicolumn{2}{|c|}{ Developing from absent $\leq 3$ seconds } & \\
\hline & Gradual & \multicolumn{2}{|c|}{ Developing from absent $>3$ seconds } & \\
\hline \multirow{5}{*}{$\begin{array}{l}\text { Morphology } \\
\text { patterns }\end{array}$} & $\begin{array}{l}\text { Spike } \\
\text { Wave }\end{array}$ & \multicolumn{2}{|c|}{$\begin{array}{l}\text { SW discharges or RDA with superimposed repetitive } \\
\text { sharp waves or spikes (RDA+S) }\end{array}$} & \\
\hline & Wave & \multicolumn{2}{|l|}{ RDA } & \\
\hline & Fast Spike & \multicolumn{2}{|c|}{ Spiky or sharp periodic discharges } & \\
\hline & $\begin{array}{l}\text { Seizure- } \\
\text { related } \\
\text { EMG } \\
\text { Artifacts }\end{array}$ & \multicolumn{2}{|c|}{ Electromyography artifacts caused by seizures } & \\
\hline & $\begin{array}{l}\text { Unknown } \\
\text { Type }\end{array}$ & \multicolumn{2}{|c|}{ Other patterns than the above four } & \\
\hline
\end{tabular}


medRxiv preprint doi: https://doi.org/10.1101/2020.10.02.20205583; this version posted October 9, 2020. The copyright holder for this preprint (which was not certified by peer review) is the author/funder, who has granted medRxiv a license to display the preprint in All rights reserved. No reuse allowed without permission.

We summarized the annotated ictal discharges by the two raters via an annotation code (appendix $A$ ), and estimated the inter-rater agreement. Cohen's kappa was calculated to assess the agreement on episodes with and without ictal discharges. Fleiss' kappa was estimated to assess the agreement on episodes with definite ictal discharges, with possible ictal discharges, and without ictal discharges. The $95 \%$ confidence interval (CI) of the kappa statistics were also calculated. The level of the agreement was interpreted according to the suggestions of Landis and Koch ${ }^{22}$.

\subsection{Investigation of unreliable EEG interpretations through visual analysis}

We applied linear regression models to determine whether the reliability of EEG interpretations, quantified by the inter-rater agreement, was influenced by the characteristics of ictal discharges and the clinical data of subjects. Two models with Cohen's kappa and Fleiss' kappa as the dependent variables were fitted. The independent variables were the characteristics of ictal discharges (duration, certainty, onset location, onset visibility, and morphology patterns) and the clinical data (age, sex, intellectual disability level, sleep status, preexisting epileptic encephalopathy, clinical signs during NCSE, and seizure history). The analysis was implemented in SPSS Statistics version 25. A two-tailed p-value $<0.05$ indicated a significant linear relationship.

\subsection{Analysis of EEG misinterpretations through visual and automated analysis}

Comparing the EEG interpretations from visual and automated analysis can help us point out the hidden pitfalls. Therefore, we developed a customized multimodal viewer (a Matlab graphical user interface shown in figure 1) that presents the EEG recordings, the annotated ictal discharges by raters, and the EEG signal classification results generated by our in-house automated analysis 
medRxiv preprint doi: $h t t p s: / / d o i . o r g / 10.1101 / 2020.10 .02 .20205583 ;$ this version posted October 9, 2020. The copyright holder for this preprint (which was not certified by peer review) is the author/funder, who has granted medRxiv a license to display the preprint in All rights reserved. No reuse allowed without permission.

system. The automated analysis system included pre-processing, feature extraction, and synthetic three-class classification (more details can be found in appendix $B$ ). The system mainly analyzed features in time-frequency domain and built a synthetic three-class classifier to classify EEG epochs into three categories: ictal discharges, suspicious activity, and normal activity. The suspicious activity indicated the misinterpreted EEG signals (signals misclassified as ictal discharges) in the automated analysis. In the lower panel of the multimodal viewer (figure 1), the distribution of the three categories were presented in units of 10 seconds.

Two epileptologists investigated and discussed the pitfalls of EEG misinterpretations for each subject. They used the multimodal viewer to compare the EEG interpretations through the visual and automated analysis. Meanwhile, they checked the corresponding clinical data and inter-rater agreement. The pitfalls of EEG misinterpretations in the automated analysis were investigated among the EEG episodes without annotated ictal discharges but automatically classified as definite or suspected ictal discharges. The pitfalls of EEG misinterpretations in the visual analysis were investigated among the EEG episodes with annotated ictal discharges but automatically classified as normal activity 

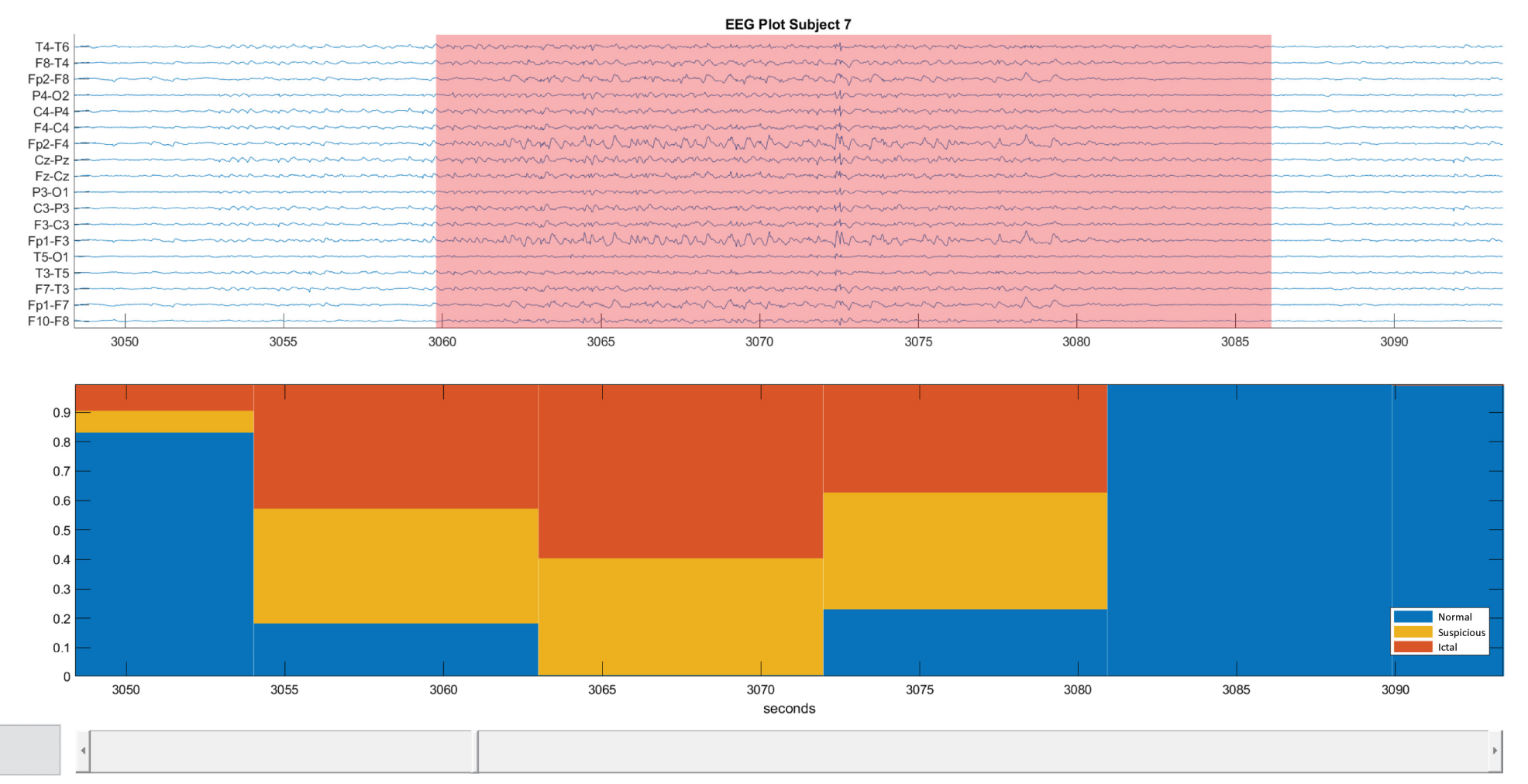

Figure 1. Viewer for EEG recording and classification results. The upper panel in the viewer presents an EEG recording in the longitudinal bipolar montage.

Pink backgrounds indicate ictal discharges. The lower panel shows the stacked percentages of the classification results. Each bin in the bar plot indicates 10 seconds. The upper and lower panels are linked, and both of them are able to be zoomed in or out.

EEG: electroencephalography. 
medRxiv preprint doi: https://doi.org/10.1101/2020.10.02.20205583; this version posted October 9, 2020. The copyright holder for this preprint (which was not certified by peer review) is the author/funder, who has granted medRxiv a license to display the preprint in All rights reserved. No reuse allowed without permission.

\section{Results}

\subsection{Subjects}

The subject flow through the three study phases is shown in a recruitment tree (figure 2). In the first phase, two subjects were excluded, and two were moved from the diagnosed NCSE group to the suspected NCSE group. In the second phase, the EEG recordings of two subjects in the NCSE group and nine subjects in the suspected NCSE group did not include any agreed annotated ictal discharges. All 16 subjects in the NCSE group were included in the third phase for the statistical analysis. Fourteen of the 16 subjects were used in the automated EEG analysis system development. In addition, two, nine, and five of the 16 subjects' EEG recordings in the NCSE group were sampled at $100 \mathrm{~Hz}, 200 \mathrm{~Hz}$, and $256 \mathrm{~Hz}$, respectively. In the suspected NCSE group, one subject's recording was sampled at $200 \mathrm{~Hz}$, and the others were at $256 \mathrm{~Hz}$.

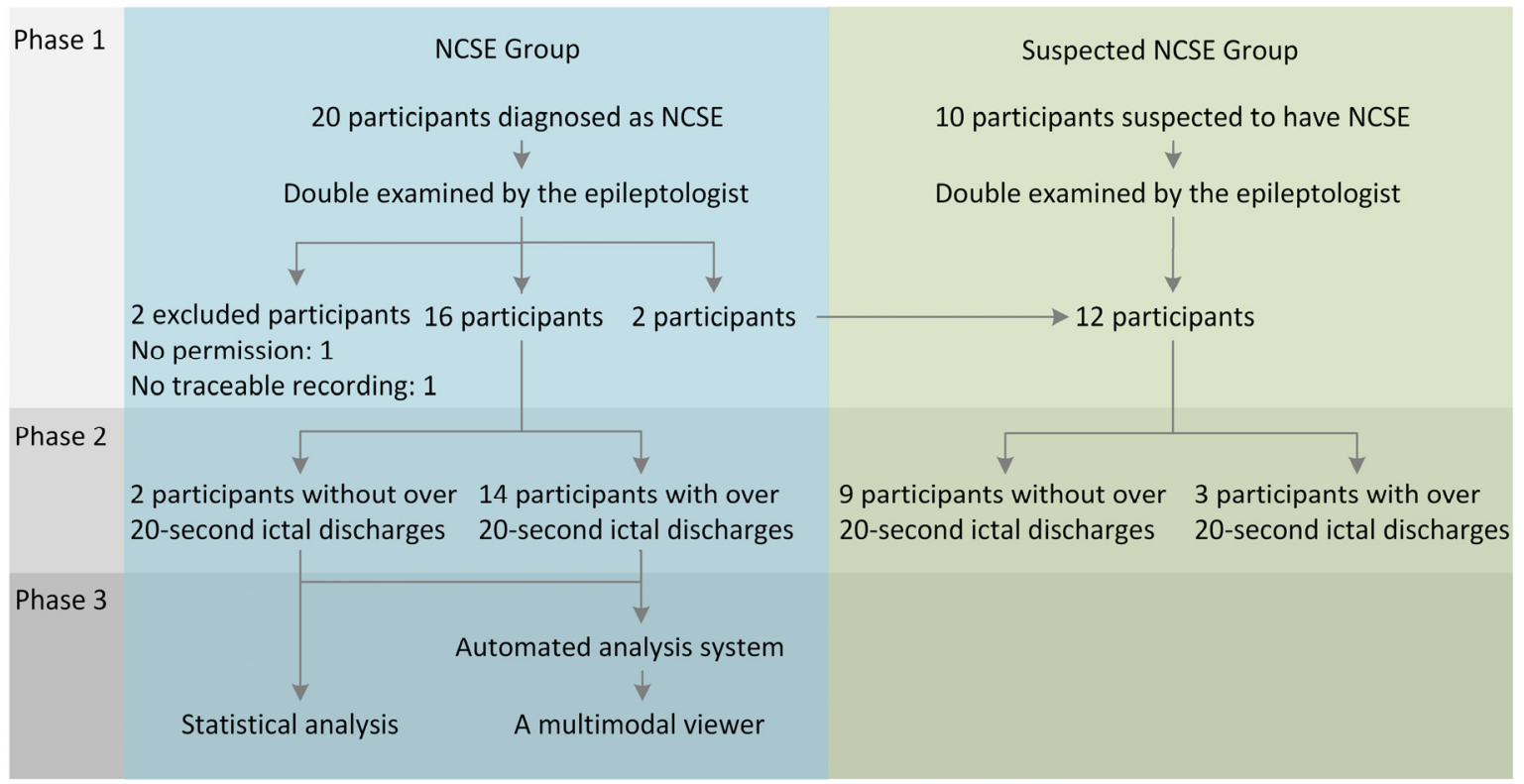

Figure 2. Recruitment tree. 
medRxiv preprint doi: https://doi.org/10.1101/2020.10.02.20205583; this version posted October 9, 2020. The copyright holder for this preprint (which was not certified by peer review) is the author/funder, who has granted medRxiv a license to display the preprint in perpetuity.

All rights reserved. No reuse allowed without permission.

In the first phase, the median age of the 16 NCSE subjects was 21 years, ranging from 6 to 43 years, and the median age of the 12 suspected NCSE subjects was 19 years, ranging from 4 to 61 years. Figure 3 presents an overview of the demographics and the clinical characteristics of the subjects. Of note, two of 16 NCSE subjects had preexisting epileptic encephalopathy, whereas in the suspected NCSE group, the subjects with and without preexisting epileptic encephalopathy were equally distributed. Moreover, the EEG recording duration in the suspected NCSE group is generally shorter than that in the NCSE group. A more comprehensive list of the clinical signs, seizure histories, and other characteristics of individual NCSE and suspected NCSE subjects are provided in appendix $C$.

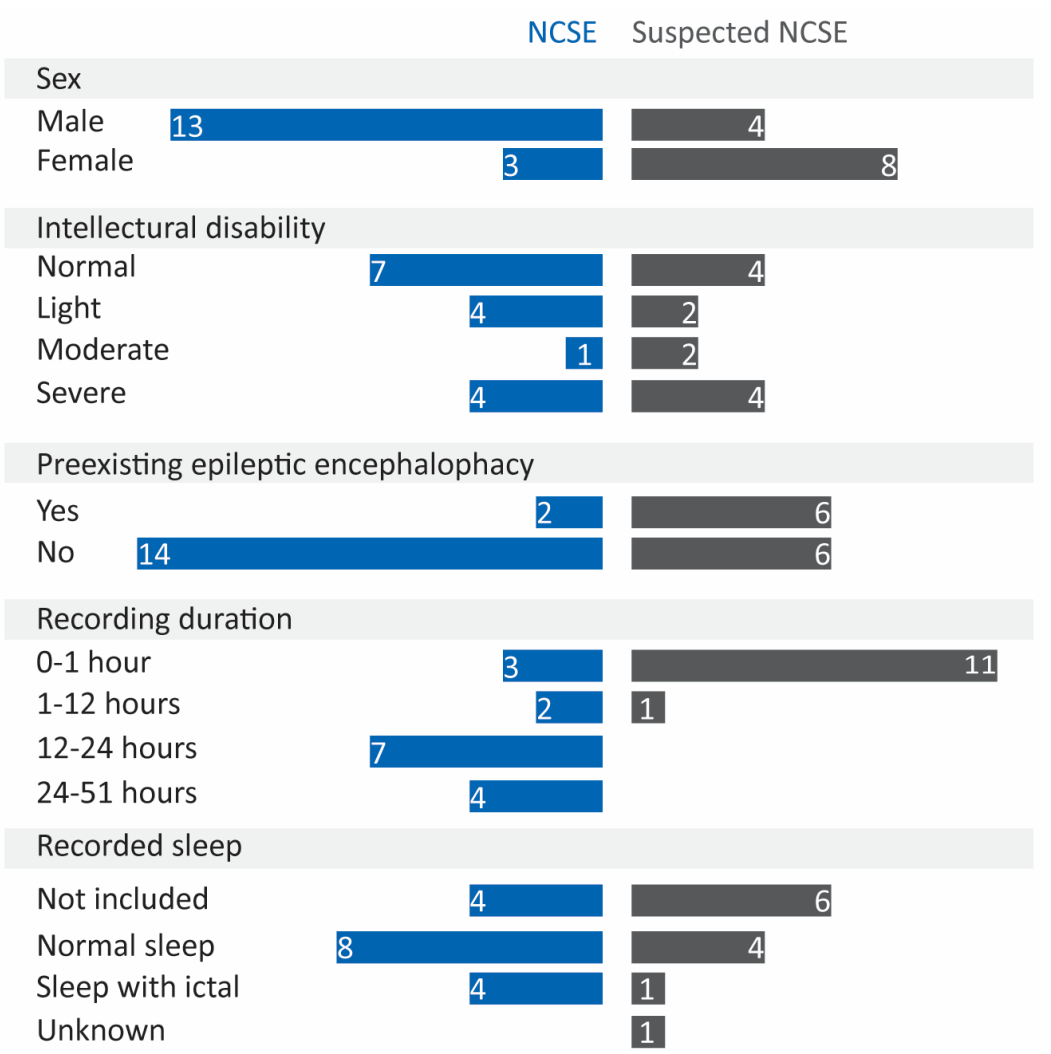

Figure 3. The overview of the demographics and the clinical characteristics of the subjects in the NCSE and suspected NCSE groups.

NCSE: non-convulsive status epilepticus. 
medRxiv preprint doi: https://doi.org/10.1101/2020.10.02.20205583; this version posted October 9 , 2020. The copyright holder for this preprint (which was not certified by peer review) is the author/funder, who has granted medRxiv a license to display the preprint in All rights reserved. No reuse allowed without permission.

\subsection{Inter-rater agreement of visual EEG interpretations}

In the NCSE group, the inter-rater agreement for both two categories (episodes with ictal discharges and without ictal discharges) and three categories (episodes with possible ictal discharges, with definite ictal discharges, and without ictal discharges) was moderate, with Cohen's kappa $=0.53$ and 95\% CI [0.37, 0.69], and Fleiss' kappa $=0.41$ and 95\% CI $[0.25,0.57]$, respectively. The inter-rater agreement of the individual subjects are shown in appendix $D$. In the suspected NCSE group, the inter-rater agreement was poor (Cohen's kappa $=0$; Fleiss' kappa = 0.08); hence, we did not further analyze the EEG recordings in this group.

\subsection{Annotated ictal discharges in the NCSE group}

In the NCSE group, 338 ictal discharges were annotated among approximately 183 hours of EEG recordings. The annotated ictal discharges lasted approximately 14.7 hours in total. The ictal discharges were summarized (figure 4) according to their characteristics: the certainty, onset location, onset visibility, and morphology patterns. The definite and possible ictal discharges each accounted for similar proportions. With respect to the onset location, generalized ictal discharges reached major proportions. In addition, the ictal discharges with a sudden onset, developing from absent in less than or equal to 3 seconds, accounted for a slightly higher proportion than the ictal discharges with a gradual onset, developing from absent in more than 3 seconds. Morphologically, the vast majority (66\%) of the ictal discharges had a "Spike Wave" pattern. 
medRxiv preprint doi: https://doi.org/10.1101/2020.10.02.20205583; this version posted October 9, 2020. The copyright holder for this preprint (which was not certified by peer review) is the author/funder, who has granted medRxiv a license to display the preprint in

All rights reserved. No reuse allowed without permission.

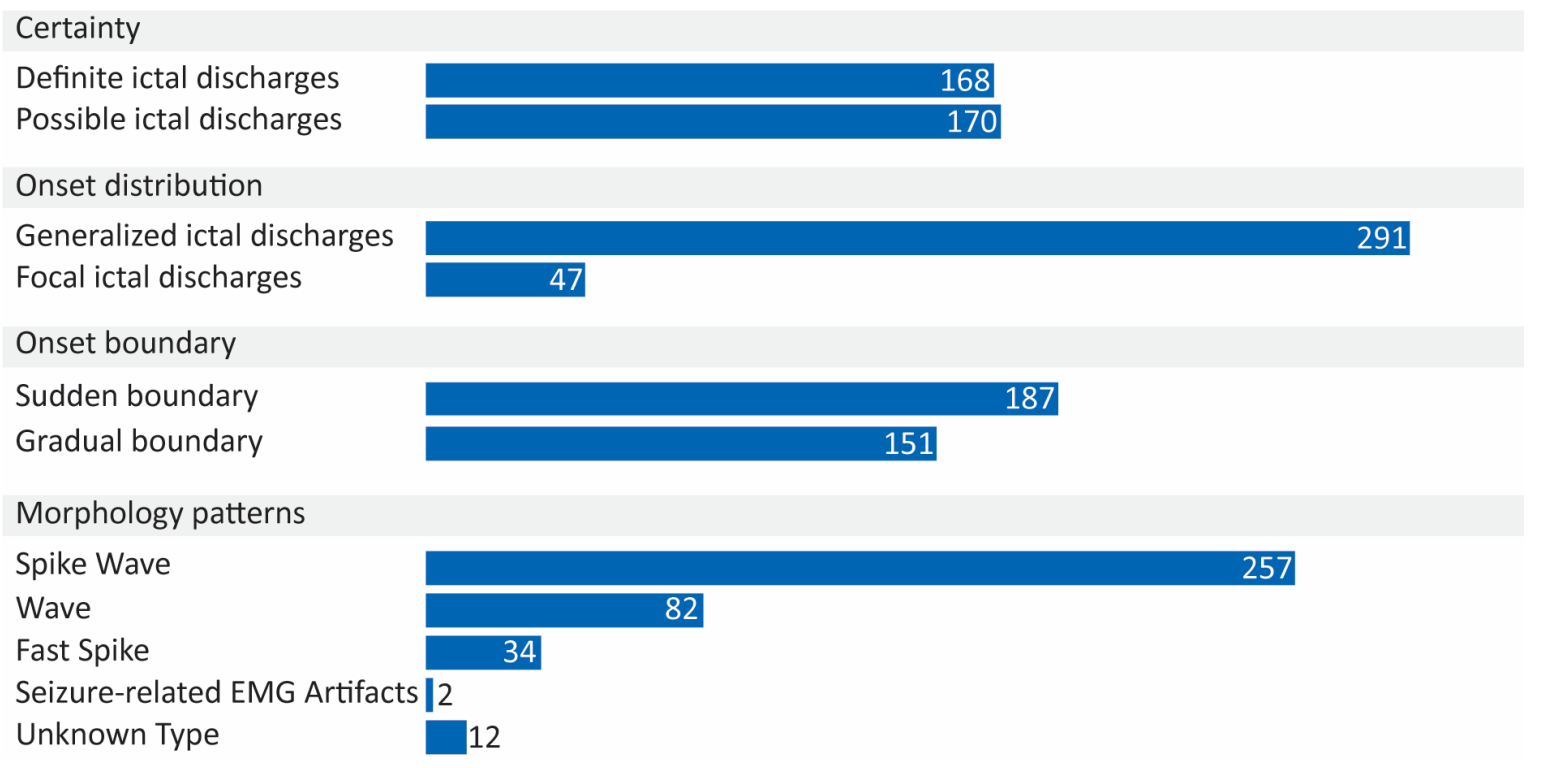

Figure 4. The number of the ictal discharges categorized by their characteristics.

\subsection{Pitfalls of unreliable EEG interpretations through visual EEG analysis}

Linear models showed a significant relationship between the average duration of the ictal discharges with a gradual onset and inter-rater agreement measured by the kappa statistics. For Cohen's kappa, $\beta=0.001, F(1,14)=10.861, p=0.005$, and the independent variable (the average duration) explained $43.7 \%$ of the variability. For Fleiss's kappa, $\beta=0.001, F(1,14)=12.89$, $p=$ 0.003 , and the independent variable explained $44.2 \%$ of the variability. In other words, an extra 2 minutes of the ictal discharges with a gradual onset contributed to an increase in the kappa statistics of $>0.1$. This implies that human raters interpreted ictal discharges with a gradual onset less reliably when the duration was shorter. Using a short duration criterion in annotating these ictal discharges could be a pitfall in visual EEG analysis (table 2). 
medRxiv preprint doi: https://doi.org/10.1101/2020.10.02.20205583; this version posted October 9, 2020. The copyright holder for this preprint (which was not certified by peer review) is the author/funder, who has granted medRxiv a license to display the preprint in

All rights reserved. No reuse allowed without permission.

Table 2. Pitfalls in EEG interpretations.

Pitfalls of unreliable EEG interpretations through visual analysis

Using a short duration criterion in annotating ictal with a gradual onset

Pitfalls of EEG over-interpretations

Misinterpretation of abnormal background activity:

- Misinterpretation of slow wave activities observed in a dysfunctional brain or in a drowsy stage;

- Assuming that the EEG background of individual subjects was consistently normal, and over-interpreting the abnormalities as ictal;

- Misinterpretation of the envelope of ictal-like movement artifacts leads to false alarms in computer-assisted EEG analysis

Misinterpretation of continuous interictal discharges

Misinterpretation of continuous short ictal discharges

EEG: electroencephalography.

\subsection{Expert opinion of the reasons of misinterpretations by visual and automated EEG analysis}

The epileptologists summarized the pitfalls of EEG misinterpretations using the multimodal viewer. The pitfalls were the misinterpretation of the following:

- abnormal background activity (figure 5A-C),

- continuous interictal discharges (figure 5D),

- continuous short ictal discharges (figure 5E) whose duration were shorter than 20 seconds. 
medRxiv preprint doi: https://doi.org/10.1101/2020.10.02.20205583; this version posted October 9, 2020. The copyright holder for this preprint (which was not certified by peer review) is the author/funder, who has granted medRxiv a license to display the preprint in All rights reserved. No reuse allowed without permission.

A

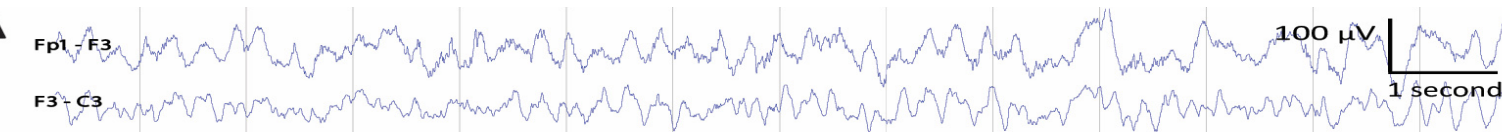

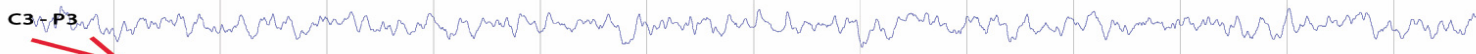

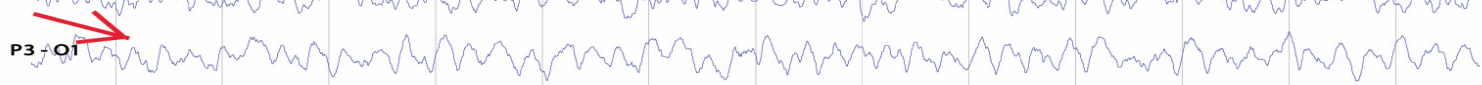

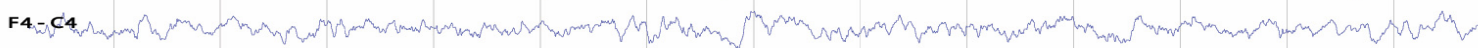

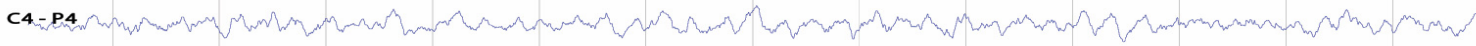

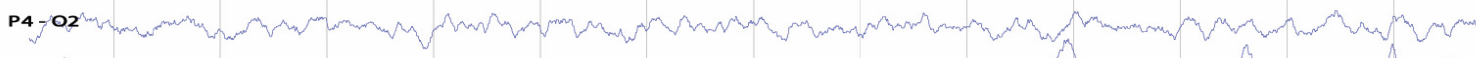

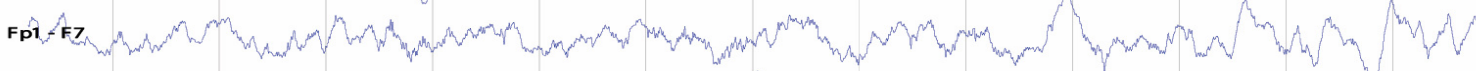

B FPa

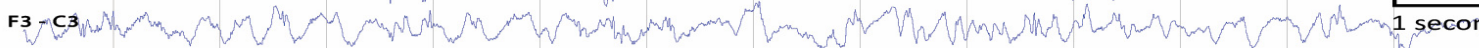
Cz-P.3.

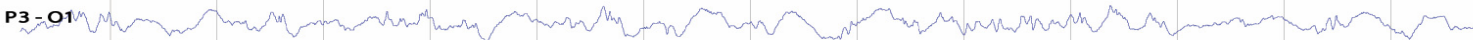

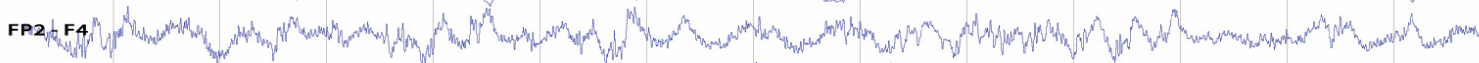

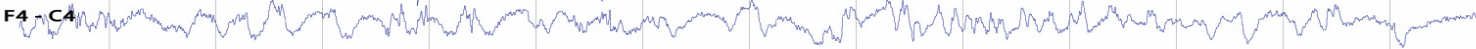

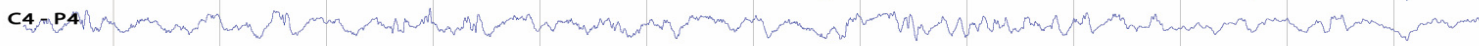

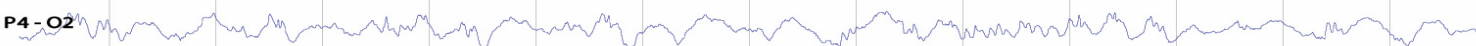

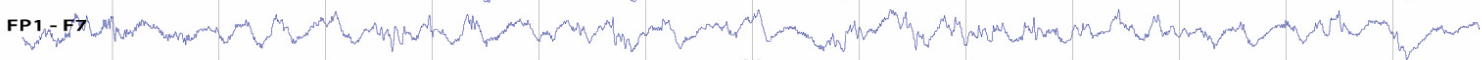

C

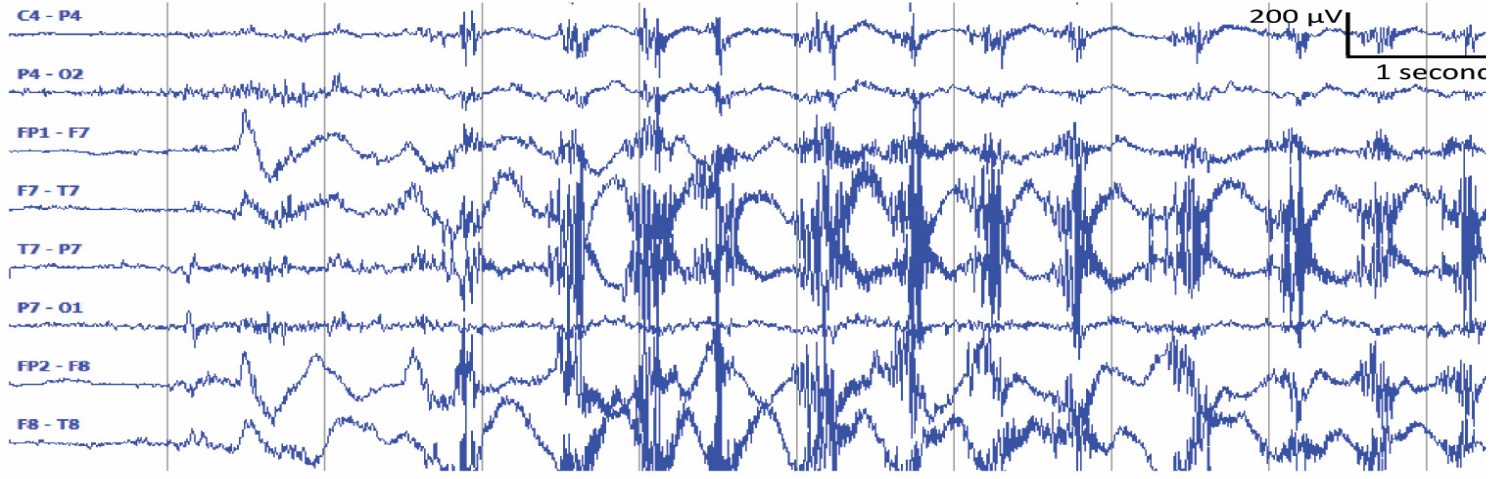

$D_{\text {EP1-F3 }} \geq$

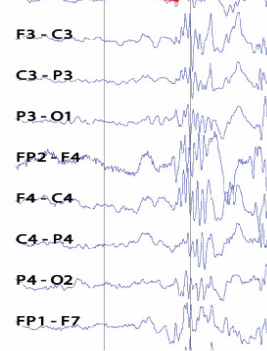

$E_{\text {rrives }}$ Pै

F3- C3

C3,- P3

P3-OT

$\mathrm{FP}^{2}=\mathrm{F} 4$

F4- 44

C4-P4

P4-02
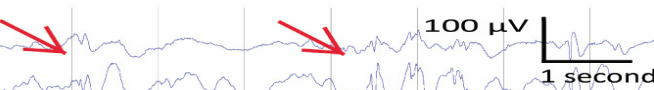

Figure 5. Abnormal background activity. (A) Slow wave activities marked by an arrow. (B) Other abnormal brain activity. (C) Ictal-like movement artifacts. (D) Several interictal discharges. The onsets of the interictal discharges are marked by arrows. (E) Short ictal discharges. The onsets of two short ictal discharges are labeled by arrows. 
medRxiv preprint doi: https://doi.org/10.1101/2020.10.02.20205583; this version posted October 9 , 2020. The copyright holder for this preprint (which was not certified by peer review) is the author/funder, who has granted medRxiv a license to display the preprint in All rights reserved. No reuse allowed without permission.

The abnormal background activity was categorized in three types: slow wave activities (figure $5 \mathrm{~A}$ ) regularly observed in a dysfunctional brain or in a drowsy stage, other abnormal brain activity (figure 5B) whose appearance was subject-dependent, and ictal-discharge-like movement artifacts caused by rhythmic movements, such as repetitive chewing movements (figure $5 C$ ). The pitfalls of misinterpretations are summarized in table 2, and the remarks by the epileptologists are provided in appendix $E$.

\section{Discussion}

A reliable and correct EEG interpretation to diagnose NCSE is currently still difficult from visual as well as automated analysis $5,18,23$. In this retrospective study, we visually and automatically analyzed NCSE-EEG recordings, and the inter-rater agreement in the NCSE group was moderate $($ Cohen's kappa $=0.53$ and Fleiss' kappa $=0.41)$, consistent with the findings by Goselink et al. 5 . We found that using a short duration criterion for ictal discharges with a gradual onset contributed to an unreliable EEG interpretation. Moreover, we pointed out other facts for EEG misinterpretation: abnormal background activity, continuous interictal discharges, and continuous short ictal discharges, which extended the findings of a previous study ${ }^{10}$.

One pitfall was to use a short ictal duration criterion for ictal discharges with a gradual onset. In this study, we set 20 seconds as the duration criterion for ictal discharges, but even then the interrater agreement was still low. The 10 -second criterion in SCC ${ }^{12}$, defined according to commonly used EEG reading duration via software, could be too short to support the reliability of visual EEG interpretations in clinical practice. To increase the reliability of NCSE diagnosis and conform to 
medRxiv preprint doi: https://doi.org/10.1101/2020.10.02.20205583; this version posted October 9, 2020. The copyright holder for this preprint (which was not certified by peer review) is the author/funder, who has granted medRxiv a license to display the preprint in All rights reserved. No reuse allowed without permission.

the natural course of the disease, a longer duration criterion can be recommended in future, especially when EEG-readers rate ictal discharges with a gradual onset. However, using a too long duration criterion might increase the risk of ignoring intervals carrying essential information. Further research should be undertaken into optimal length. Until now, automated EEG analysis algorithms for NCSE have regularly used short (e.g., 3 seconds) EEG signals as a classification epoch, but the epoch duration is too short to be used in reliably detecting the ictal discharges for NCSE diagnosis according to the earlier discussion. To be consistent with the way clinicians diagnose NCSE, future studies about automated EEG analysis algorithms should focus on ictal discharge detection using longer-duration EEG epochs.

The pitfalls of EEG misinterpretations in both visual and automated analysis were misinterpreting the following as ictal discharges: (1) abnormal background activity [(a) slow wave activities, (b) other abnormal brain activity, and (c) the ictal-like movement artifacts], (2) continuous interictal discharges, and (3) continuous short ictal discharges.

(1) For the three types of activities of the abnormal background activity:

(a) Slow wave activities are frequently observed in a damaged brain (e.g., in epileptic encephalopathies) or during drowsiness. In visual analysis, EEG readers with insufficient training in reading EEGs from a dysfunctional brain or sleep-EEG may misinterpret the EEG ${ }^{18}$. In automated analysis, slow wave activities and ictal discharges could be confused because their frequency bands are similar. An advanced signal processing technique, such as extracting features in the morphological besides the time-frequency domain features ${ }^{24}$, may be helpful in their distinction in future studies. 
medRxiv preprint doi: https://doi.org/10.1101/2020.10.02.20205583; this version posted October 9, 2020. The copyright holder for this preprint (which was not certified by peer review) is the author/funder, who has granted medRxiv a license to display the preprint in All rights reserved. No reuse allowed without permission.

(b) The other abnormal brain activity is individually variable, and can be avoided by the use of historical EEG data. Its misinterpretation (false alarms) in automated analysis was also mentioned in the previous studies ${ }^{8,9}$.

(c) The ictal-like movement artifacts could be misinterpreted in automated analysis when their repetitive movements have a similar frequency band as ictal discharges. The low-pass filter of the analysis algorithms helps filter out high-frequency components caused by muscle activities, but keeps the envelope of signals caused by the repetitive movements.

In summary, to avoid misinterpretation of abnormal background activity, we suggest reading more EEG recordings from the same subject to help human raters better recognize subject-specific ictal discharges and individualizing automated analysis algorithms.

(2) Interictal discharges are not always clearly distinct from ictal discharges, and misinterpretation of continuous interictal discharges occurs especially in patients with encephalopathy ${ }^{10}$. The duration and presence of repetitive spiking or bursting activity cannot be the only criteria to identify interictal discharges by EEG readers ${ }^{25}$. Further investigation of criteria for interictal discharges is needed.

(3) High concentrations of short ictal discharges can be observed in the EEG recording of a subject presenting many short and unstable epileptic activities. Raters with hyper-sensitivity may misinterpret them as ictal discharges. We would suggest that EEG readers carefully interpret such EEG recordings and consult other readers if in doubt. In addition, we recommend tuning alarm thresholds according to subject-dependent clinical practice in the automated EEG analysis for these particular recordings. 
medRxiv preprint doi: https://doi.org/10.1101/2020.10.02.20205583; this version posted October 9, 2020. The copyright holder for this preprint (which was not certified by peer review) is the author/funder, who has granted medRxiv a license to display the preprint in All rights reserved. No reuse allowed without permission.

One unanticipated finding is that the inter-rater agreement in the suspected NCSE group was poor. Based on our previous discussions and the clinical data of the suspected NCSE subjects, we could assume that two factors may explain the unreliable EEG interpretations in this group. (1) Almost all the recordings were less than 1 hour, and the raters may not have had enough EEG recordings from the same subject to correctly distinguish ictal discharges from the abnormal background activity. (2) Half of the subjects had preexisting epileptic encephalopathy. The slow wave activities and the interictal discharges in the subjects with encephalopathy were probably misinterpreted as ictal discharges. Additional studies are needed to confirm the causes of the poor inter-rater agreement in the EEG interpretations of patients with suspected NCSE.

This study has several limitations. Given that the number of recordings from patients with NCSE at Kempenhaeghe is relatively small, we also included several discontinuous archived EEG recordings. These discontinuous recordings may hinder human readers and automatic algorithms from correctly interpreting EEG. Continuous recordings from more data sources should be used in future. The EEG-recordings were acquired by three systems, and their sampling rate were different [the lowest sampling rate was $100 \mathrm{~Hz}(\mathrm{n}=2)]$. The heterogeneity of the sampling rate was not expected to affect our results, such as the problem of the aliasing, because the frequency band of interest, such as the frequency range occupied by Spike Wave and Wave patterns, is much lower than $50 \mathrm{~Hz}$. Nevertheless, future works should be undertaken to further confirm the influence of the different system hardware and setting-up on our results. Given that this is an explorative study, the number of recruited subjects $(n=30)$, EEG readers $(n=2)$, and research centers $(n=1)$ was small; hence, the generalization of the conclusions is limited. In addition, given that our study is explorative and a large population of patient requires a large sample size, the subjects included in 
medRxiv preprint doi: https://doi.org/10.1101/2020.10.02.20205583; this version posted October 9,2020 . The copyright holder for this preprint (which was not certified by peer review) is the author/funder, who has granted medRxiv a license to display the preprint in All rights reserved. No reuse allowed without permission.

this study were outpatients with chronic seizures and brain development disorders, and their age ranged between 4 and 61 years; thus, the conclusions do not extend beyond this population. Future work should include more subjects, especially those of neonatal age, elderly patients, patients without preexisting epilepsy, and ICU patients, and more EEG readers from different research centers for the generalizability. In the development of the automated EEG analysis algorithm, we primarily used time-frequency domain features, which limited our conclusion of the pitfalls in the automated analysis. In future, morphological features should be added to the automated analysis.

\section{Conclusion}

We visually and automatically analyzed NCSE-EEG recordings to explore the causes of EEG misinterpretations. To avoid the pitfalls in NCSE-EEG analysis, a longer duration criterion than the one suggested by the Salzburg criteria is needed. Using knowledge of historical EEGs, individualized algorithms, and context-dependent alarm thresholds may also avoid mistakes.

\section{Acknowledgements.}

This work is part of the research program BrainWave with project number 14714, which is (partly) financed by the Netherlands Organization for Scientific Research (NWO).

\section{Disclosures.}

None of the authors have potential conflicts of interest to be disclosed 
medRxiv preprint doi: https://doi.org/10.1101/2020.10.02.20205583; this version posted October 9, 2020. The copyright holder for this preprint (which was not certified by peer review) is the author/funder, who has granted medRxiv a license to display the preprint in perpetuity.

All rights reserved. No reuse allowed without permission.

\section{References}

1. Trinka E, Cock H, Hesdorffer D, et al. A definition and classification of status epilepticus - Report of the ILAE Task Force on Classification of Status Epilepticus. Epilepsia. 2015;56(10):15151523. doi:10.1111/epi.13121

2. Stroink H, Schimsheimer R-J, de Weerd AW, et al. Interobserver reliability of visual interpretation of electroencephalograms in children with newly diagnosed seizures. Dev Med Child Neurol. 2006;48(05):374. doi:10.1017/S0012162206000806

3. Grant AC, Abdel-Baki SG, Weedon J, et al. EEG interpretation reliability and interpreter confidence: A large single-center study. Epilepsy Behav. 2014;32:102-107. doi:10.1016/j.yebeh.2014.01.011

4. Ronner HE, Ponten SC, Stam CJ, Uitdehaag BMJ. Inter-observer variability of the EEG diagnosis of seizures in comatose patients. Seizure. 2009;18(4):257-263. doi:10.1016/j.seizure.2008.10.010

5. Goselink RJM, van Dillen JJ, Aerts M, et al. The difficulty of diagnosing NCSE in clinical practice; external validation of the Salzburg criteria. Epilepsia. 2019;60(8):e88-e92. doi:10.1111/epi.16289

6. Sackellares JC, Shiau D-S, Halford JJ, LaRoche SM, Kelly KM. Quantitative EEG analysis for automated detection of nonconvulsive seizures in intensive care units. Epilepsy Behav. 2011;22:S69-S73. doi:10.1016/J.YEBEH.2011.08.028

7. Priyanka Sharma, Yusuf Uzzaman Khan, Omar Farooq, Manjar Tripathi, Hojjat Adeli. A WaveletStatistical Features Approach for Nonconvulsive Seizure Detection. Clin EEG Neurosci. 2014;45(4):274-284. doi:10.1177/1550059414535465

8. Aldana YR, Hunyadi B, Reyes EJM, Rodriguez VR, Van Huffel S. Nonconvulsive Epileptic Seizure Detection in Scalp EEG Using Multiway Data Analysis. IEEE J Biomed Heal Informatics. 2019;23(2):660-671. doi:10.1109/JBHI.2018.2829877

9. Khan YU, Farooq O, Tripathi M, Sharma P, Alam P. Automatic detection of non-convulsive seizures using AR modeling. In: 2012 2nd International Conference on Power, Control and Embedded Systems. IEEE; 2012:1-4. http://ieexplore.ieee.org/document/6508099/. Accessed April 3, 2019.

10. Gaspard N, Hirsch LJ. Pitfalls in ictal EEG interpretation. Neurology. 2013;80(1 Supplement 1):S26-S42. doi:10.1212/WNL.0b013e31827974f8

11. Beniczky S, Hirsch LJ, Kaplan PW, et al. Unified EEG terminology and criteria for nonconvulsive status epilepticus. Epilepsia. 2013;54(SUPPL. 6):28-29. doi:10.1111/epi.12270

12. Leitinger M, Beniczky S, Rohracher A, et al. Salzburg Consensus Criteria for Non-Convulsive Status Epilepticus - approach to clinical application. Epilepsy Behav. 2015;49:158-163. doi:10.1016/j.yebeh.2015.05.007

13. Leitinger M, Trinka E, Gardella E, et al. Diagnostic accuracy of the Salzburg EEG criteria for nonconvulsive status epilepticus: a retrospective study. Lancet Neurol. 2016;15(10):1054-1062.

doi:10.1016/S1474-4422(16)30137-5 
medRxiv preprint doi: https://doi.org/10.1101/2020.10.02.20205583; this version posted October 9, 2020. The copyright holder for this preprint (which was not certified by peer review) is the author/funder, who has granted medRxiv a license to display the preprint in perpetuity.

All rights reserved. No reuse allowed without permission.

14. Krogstad MH, Høgenhaven H, Beier CP, Krøigård T. Nonconvulsive Status Epilepticus: Validating the Salzburg Criteria Against an Expert EEG Examiner. J Clin Neurophysiol. 2019;36(2):141-145. doi:10.1097/WNP.0000000000000556

15. Goselink RJM, Dillen JJ, Zwarts M, Alfen N. Response: The difficulty of diagnosing nonconvulsive status epilepticus in clinical practice. Epilepsia. 2019;60(11):2337-2338. doi:10.1111/epi.16365

16. Leitinger M, Trinka E, Zimmermann G, Beniczky S. Salzburg criteria for nonconvulsive status epilepticus: Details matter. Epilepsia. 2019;60(11):2334-2336. doi:10.1111/epi.16361

17. Benbadis SR. The tragedy of over-read EEGs and wrong diagnoses of epilepsy. Expert Rev Neurother. 2010;10(3):343-346. doi:10.1586/ern.09.157

18. Arends JB, van der Linden I, Ebus SC, Debeij MH, Gunning BW, Zwarts MJ. Value of reinterpretation of controversial EEGs in a tertiary epilepsy clinic. Clin Neurophysiol. 2017;128(4):661-666. doi:10.1016/J.CLINPH.2016.12.010

19. Teunis van Beelen. EDFbrowser. https://www.teuniz.net/edfbrowser/index.html. Published 2018. Accessed August 1, 2018.

20. Hirsch LJ, LaRoche SM, Gaspard N, et al. American Clinical Neurophysiology Society's Standardized Critical Care EEG Terminology. J Clin Neurophysiol. 2013;30(1):1-27. doi:10.1097/WNP.0b013e3182784729

21. Wang L, Arends JBAM, Long X, Cluitmans PJM, van Dijk JP. Seizure pattern-specific epileptic epoch detection in patients with intellectual disability. Biomed Signal Process Control. 2017;35:38-49. doi:10.1016/j.bspc.2017.02.008

22. Landis JR, Koch GG. The Measurement of Observer Agreement for Categorical Data. Biometrics. 1977;33(1):159-174. doi:10.2307/2529310

23. Williams GW, Lüders HO, Brickner A, Goormastic M, Klass DW. Interobserver variability in EEG interpretation. Neurology. 1985;35(12):1714-1719.

http://www.ncbi.nlm.nih.gov/pubmed/4069362. Accessed March 8, 2019.

24. Wang Y, Long X, van Dijk JP, Aarts RM, Wang L, Arends JBAM. False alarms reduction in nonconvulsive status epilepticus detection via continuous EEG analysis. Physiol Meas. 2020;41(5):055009. doi:10.1088/1361-6579/ab8cb3

25. Fisher RS, Scharfman HE, DeCurtis M. How Can We Identify Ictal and Interictal Abnormal Activity? In: Scharfman H, Buckmaster P, eds. Issues in Clinical Epileptology: A View from the Bench. Advances in Experimental Medicine and Biology. Springer, Dordrecht; 2014:3-23. http://link.springer.com/10.1007/978-94-017-8914-1_1. Accessed April 15, 2019. 